\title{
Aerobic Biodegradation of Four Groups of Steroid Hormones in Activated Sludge
}

\author{
Jiaxin Zhang, Jun Luo, and Hong Chang \\ Beijing Key Lab for Source Control Technology of Water Pollution, College of Environmental Sciences \& Engineering, \\ Beijing Forestry University, Beijing 100083, China \\ Correspondence should be addressed to Hong Chang; changh@bjfu.edu.cn
}

Received 4 December 2019; Accepted 12 February 2020; Published 9 March 2020

Guest Editor: Yihua Xiao

Copyright $(2020$ Jiaxin Zhang et al. This is an open access article distributed under the Creative Commons Attribution License, which permits unrestricted use, distribution, and reproduction in any medium, provided the original work is properly cited.

Steroid hormones in the environment have obtained considerable attention, as they can be harmful to aquatic organisms at very low concentrations. An analytical method was developed for simultaneously monitoring four estrogens, seven androgens, seven progestogens, and eleven glucocorticoids in a single water sample using liquid chromatography-electrospray tandem mass spectrometry. Laboratory studies were then performed to investigate the aerobic biodegradation of 29 steroids belonging to the four groups. The degradation of target steroids followed first-order reaction kinetics, and the degradation half-life $\left(t_{1 / 2}\right)$ of estrogens, androgens, progestogens and glucocorticoids was $1.2-8.7 \mathrm{~h}, 0.3-1.3 \mathrm{~h}, 1.4-7.7 \mathrm{~h}$, and $1.4-23.1 \mathrm{~h}$, respectively. Most of the esterified glucocorticoids were more persistent than the parent compounds, but the $t_{1 / 2}$ for halogenated glucocorticoids was longer than that of their esterified compounds. In addition, C-21 ester glucocorticoids were more prone to decomposition than C-17 esters. Hydrolysis did not significantly affect the decomposition of esterified steroids.

\section{Introduction}

The presence of endocrine-disrupting chemicals (EDCs) in the environment is of wide concern throughout the world. Among EDCs, steroidal estrogens have obtained considerable attention, as they can be harmful to aquatic organisms, such as fish and amphibians, at very low concentrations $[1,2]$. In addition to estrogens, other steroid hormones such as androgens, progestogens, and glucocorticoids have recently been documented to present a risk to exposed organisms [3-5]. Therefore, the occurrence and fate of steroid hormones other than estrogens in the environment deserve greater attention.

The presence of the four groups of steroid hormones and, in particular, estrogens in surface waters has been reported in multiple studies, and their concentrations were in the range of $\mathrm{pg} / \mathrm{L}$ to several hundreds of $\mathrm{ng} / \mathrm{L}$ [6-11]. Wastewater treatment plants (WWTPs) such as municipal and livestock WWTPs play a crucial role in restricting steroid hormones from entering riverine and coastal environments $[12,13]$. Incomplete removal of these steroids in
WWTPs could result in the contamination of surface waters. Thus, it is essential to study the biodegradation of steroids by bacteria in activated sludge, particularly that of progestogens and glucocorticoids.

Microbial processes play an essential role in steroid degradation. Such processes have been particularly well documented for the microbiological degradation of estrogens and androgens [14-19]. However, for progestogens and glucocorticoids, most studies have been mainly concerned about their concentrations in WWTP influents and effluents and receiving waters. To our knowledge, few studies reported the degradation kinetics of progestogens $[8,20]$ and glucocorticoids [21] by aerobic sludge. Miyamoto et al. [21] studied the fate of 10 glucocorticoids upon incubation with activated sludge and revealed different degradation behaviours for structurally different glucocorticoids. However, no studies have simultaneously investigated the microbial degradation of the four groups of steroids.

This study was performed to assess the degradation of four groups of steroids, including estrogens, androgens, progestogens, and glucocorticoids, upon treatment with 
activated sludge. A sensitive and reliable ultrahigh-performance liquid chromatography-tandem mass spectrometry (UPLC-MS/MS) method combined with liquid-liquid extraction (LLE) was developed for the simultaneous analysis of the four groups of steroids (including four estrogens, seven androgens, seven progestogens, and eleven glucocorticoids; see Table 1) in water samples. Due to the presence of isomers of the target steroids, effective chromatographic separation is essential for the unequivocal identification of specific compounds. Activated sludge was obtained from a working WWTP in Beijing, China. We simultaneously analyzed the degradation kinetics of 29 steroids during aerobic incubation with activated sludge and compared the rate of degradation among the four groups. This study will help understand their removal behaviour in the environment and consequently help accurately assess the risk of steroids hormones [22, 23].

\section{Materials and Methods}

2.1. Chemicals and Sludge Collection. Twenty-nine steroids were purchased from Sigma (St. Louis, MO, USA). Methanol, ethyl acetate, acetonitrile, acetic acid, hexane, and methylene chloride were of HPLC grade and obtained from Fisher Chemicals (Beijing, China). The activated sludge that was used as the inoculum was collected from the aerobic tank of one WWTP in Beijing, China. The slurry samples were transported back to the laboratory, stored at $4^{\circ} \mathrm{C}$, and used within $24 \mathrm{~h}$.

2.2. Microcosms. Aerobic microcosms were prepared by using fresh activated (aerobic) sludge. Incubation solutions containing $5 \%$ of each inoculum (v/v) were cultivated in a minimal-salt medium consisting of $\mathrm{KH}_{2} \mathrm{PO}_{4}(85 \mathrm{mg} / \mathrm{L})$, $\mathrm{NH}_{4} \mathrm{Cl}(5 \mathrm{mg} / \mathrm{L}), \mathrm{MgSO}_{4} \cdot 7 \mathrm{H}_{2} \mathrm{O}(22.5 \mathrm{mg} / \mathrm{L}), \mathrm{FeCl}_{3} \cdot 6 \mathrm{H}_{2} \mathrm{O}$ $(0.25 \mathrm{mg} / \mathrm{L}), \quad \mathrm{NaHPO}_{4} \cdot 2 \mathrm{H}_{2} \mathrm{O} \quad(334 \mathrm{mg} / \mathrm{L}), \quad \mathrm{CaCl}_{2} \cdot 2 \mathrm{H}_{2} \mathrm{O}$ $(36.4 \mathrm{mg} / \mathrm{L}), \mathrm{K}_{2} \mathrm{HPO}_{4}(217.5 \mathrm{mg} / \mathrm{L})$, vitamins, and trace salts, including biotin $(40 \mathrm{mg} / \mathrm{L})$, folic acid $(40 \mathrm{mg} / \mathrm{L})$, riboflavin (100 mg/L), pantothenic acid $(100 \mathrm{mg} / \mathrm{L})$, para-aminobenzoic acid $(100 \mathrm{mg} / \mathrm{L})$, niacin $(100 \mathrm{mg} / \mathrm{L})$, thiamine $(100 \mathrm{mg} / \mathrm{L})$, vitamin B6 (200 mg/L), and vitamin B12 (2 mg/L). The $\mathrm{pH}$ of the medium was adjusted to 7.0.

2.3. Degradation Experiments. The degradation experiments were performed in two groups, including groups A (test replicates) and B (sterile controls). Each group was evaluated in three $100 \mathrm{~mL}$ glass conical flasks with $25 \mathrm{~mL}$ of media containing $1.25 \mathrm{~mL}$ of activated sludge. The studied compounds were spiked into the incubation media of each treatment by adding $12.5 \mu \mathrm{L}$ of each steroid stock solution $(1000 \mathrm{mg} / \mathrm{L})$. This rendered an initial concentration of each studied compounds in each treatment of $500 \mu \mathrm{g} / \mathrm{L}$.

Three replicates (A1, A2, and A3) were used to monitor the degradation of each steroid at predetermined sampling time intervals $(0,0.5,1.0,1.5,2.0,3.0,5.0,7.0,10.0,12.0$, 24.0, 36.0, 48.0, and $60.0 \mathrm{~h}$ ). At each sampling time point, $1 \mathrm{~mL}$ of solution was removed from the same glass conical flask and transferred into a $2 \mathrm{~mL}$ amber glass vial to extract the remaining compounds of interest. For the sterile controls of each treatment (B1, B2, and B3), the glass conical flasks containing incubation media were autoclaved $\left(120^{\circ} \mathrm{C}\right.$, $30 \mathrm{~min}$ ) three times in three consecutive days prior to experimentation, followed by the addition of $0.1 \mathrm{~mL}$ of $\mathrm{HgCl}_{2}$ $(100 \mathrm{mg} / \mathrm{L})$ to maintain sterility. The target steroids were then added to each sterile control. Sterile controls for each treatment were then sampled at the same sampling points as the test groups (group A).

The treated flasks were covered with sterile sealing membranes to prevent bacteria from entering, while allowing air to circulate. The six flasks were incubated in the dark at $28^{\circ} \mathrm{C}$ with continuous shaking at $150 \mathrm{rpm}$ to maintain aerobic conditions before sampling.

2.4. Sample Pretreatment and UPLC-MS/MS Analysis. Samples $(1 \mathrm{~mL})$ were collected from the incubation media (A1-A3 and B1-B3) and extracted by $1 \mathrm{~mL}$ of ethyl acetate three times. The mixture was thoroughly mixed before each extraction using a Vortex mixer. The extracts were dried with weak nitrogen and redissolved in $200 \mu \mathrm{L}$ of methanol for analysis.

The LC apparatus was an ACQUITY Ultra Performance LC system (Waters, Milford, MA, USA). Separation was conducted using a Waters HSS T3 column $(100 \mathrm{~mm} \times 2.1 \mathrm{~mm}$, $1.8 \mu \mathrm{m}$, Waters, USA). The column was maintained at $40^{\circ} \mathrm{C}$, and the flow rate and injection volume were $0.2 \mathrm{~mL} / \mathrm{min}$ and $5 \mu \mathrm{L}$, respectively. The mobile phases consisted of acetonitrile containing acetic acid $(0.15 \%, \mathrm{v} / \mathrm{v})$ as solvent $\mathrm{A}$ and Milli-Q water containing acetic acid $(0.15 \%, v / v)$ as solvent $\mathrm{B}$. The initial gradient elution of $15 \%$ A was held for 9 min and then increased to $35 \% \mathrm{~A}$ in $4 \mathrm{~min}$ and $85 \% \mathrm{~A}$ in $5 \mathrm{~min}$. Following the gradient elution, a final elution with $15 \%$ A was held for 4 min.

Mass spectrometry was performed using a Waters Premier XE Mass Spectrometer equipped with an electrospray ionization source (Waters). A flow injection of a standard solution of each compound was used to determine the optimum conditions for the ESI source. The average parameters were source temperature, $100^{\circ} \mathrm{C}$; desolvation temperature, $350^{\circ} \mathrm{C}$; capillary voltage, $3.2 \mathrm{kV}$; desolvation gas flow rate, $800 \mathrm{~L} / \mathrm{h}$; and cone gas flow rate, $50 \mathrm{~L} / \mathrm{h}$. Quantitative analyses of the target glucocorticoids were performed in the multiselected reaction monitoring (MRM) mode. Data acquisition was performed with MassLynx 4.1 (Micromass, Manchester, U. K.).

\section{Results and Discussion}

3.1. Method Development. The 29 steroids, including four estrogens, seven androgens, seven progestogens, and eleven glucocorticoids, were simultaneously analyzed by MS/MS in the MRM mode. The two abundant MRM transitions, cone voltage and collision energies, were optimized for each analyte by infusing the standard solutions into the mass spectrometer (see Table 1). The ESI-MS/MS analyses of glucocorticoids were operated in the negative mode, while estrogen, androgen, and progestogen were operated in the positive ion mode. The precursor ions for estrogens and 
TABLE 1: Optimized instrumental and MRM conditions of the target compounds.

\begin{tabular}{|c|c|c|c|c|c|c|c|}
\hline Analyte & Abbreviation & Mode & Precursor ion & MRM transition & $\mathrm{CV}(\mathrm{V})$ & $\mathrm{CE}(\mathrm{eV})$ & $\mathrm{IDL}(\mu \mathrm{g} / \mathrm{L})$ \\
\hline \multicolumn{8}{|l|}{ Estrogens } \\
\hline Estrone & E1 & ESI+ & {$[\mathrm{M}-\mathrm{OH}]^{+}$} & $\begin{array}{l}271>147^{\mathrm{a}} \\
271>197^{\mathrm{b}}\end{array}$ & 18 & $\begin{array}{l}10 \\
17\end{array}$ & 2.0 \\
\hline$\alpha$-Estradiol & $\alpha \mathrm{E} 2$ & ESI+ & {$[\mathrm{M}-\mathrm{OH}]^{+}$} & $\begin{array}{l}255>159 \\
255>133\end{array}$ & 35 & $\begin{array}{l}20 \\
20\end{array}$ & 0.20 \\
\hline$\beta$-Estradiol & $\beta \mathrm{E} 2$ & ESI+ & {$[\mathrm{M}-\mathrm{OH}]^{+}$} & $\begin{array}{l}255>159 \\
255>133\end{array}$ & 35 & $\begin{array}{l}20 \\
20\end{array}$ & 1.0 \\
\hline Ethinylestradiol & EE2 & ESI+ & {$[\mathrm{M}-\mathrm{OH}]^{+}$} & $\begin{array}{l}279>133 \\
279>159\end{array}$ & 24 & $\begin{array}{l}20 \\
16 \\
21\end{array}$ & 1.0 \\
\hline \multicolumn{8}{|l|}{ Androgens } \\
\hline Testosterone & $\mathrm{T}$ & ESI+ & {$[\mathrm{M}+\mathrm{H}]+$} & $\begin{array}{c}289>97 \\
289>109\end{array}$ & 35 & $\begin{array}{l}20 \\
20\end{array}$ & 2.0 \\
\hline Methyl-testosterone & MT & ESI+ & {$[\mathrm{M}+\mathrm{H}]+$} & $\begin{array}{c}303>97 \\
303>109\end{array}$ & 22 & $\begin{array}{l}22 \\
15\end{array}$ & 1.8 \\
\hline epitestosterone & ET & ESI+ & {$[\mathrm{M}+\mathrm{H}]+$} & $\begin{array}{c}289>97 \\
289>109\end{array}$ & 35 & $\begin{array}{l}20 \\
20\end{array}$ & 1.5 \\
\hline Trenbolone & TBL & ESI+ & {$[\mathrm{M}+\mathrm{H}]+$} & $\begin{array}{l}271>253 \\
271>199\end{array}$ & 22 & $\begin{array}{l}18 \\
22\end{array}$ & 1.5 \\
\hline Boldenone & BOL & ESI+ & {$[\mathrm{M}+\mathrm{H}]+$} & $\begin{array}{l}287>121 \\
287>135\end{array}$ & 24 & $\begin{array}{l}22 \\
15\end{array}$ & 3.3 \\
\hline Dehydroepiandrosterone & DEHA & ESI+ & {$[\mathrm{M}+\mathrm{H}]+$} & $\begin{array}{l}271>253 \\
271>199\end{array}$ & 28 & 24 & 2.4 \\
\hline cis-Androsterone & cis-ADR & ESI+ & {$[\mathrm{M}+\mathrm{H}]+$} & $\begin{array}{l}273>255 \\
273>273\end{array}$ & 20 & $\begin{array}{l}15 \\
10\end{array}$ & 5.0 \\
\hline \multicolumn{8}{|l|}{ Progestogens } \\
\hline Progesterone & $\mathrm{P}$ & ESI+ & {$[\mathrm{M}+\mathrm{H}]+$} & $\begin{array}{c}351>109 \\
351>97\end{array}$ & 35 & $\begin{array}{l}20 \\
16\end{array}$ & 1.3 \\
\hline $21 \alpha$-Hydroxyprogesterone & $21 \alpha-\mathrm{HPT}$ & ESI+ & {$[\mathrm{M}+\mathrm{H}]^{+}$} & $\begin{array}{c}331>108 \\
331>97\end{array}$ & 28 & $\begin{array}{l}22 \\
21\end{array}$ & 1.0 \\
\hline $17 \alpha$-Hydroxyprogesterone & $17 \alpha-\mathrm{HPT}$ & ESI+ & {$[\mathrm{M}+\mathrm{H}]^{+}$} & $\begin{array}{c}331>108 \\
331>97\end{array}$ & 28 & $\begin{array}{l}22 \\
21\end{array}$ & 1.0 \\
\hline 19-Nortestosterone & $19-\mathrm{NT}$ & ESI+ & {$[\mathrm{M}+\mathrm{H}]^{+}$} & $\begin{array}{l}275>257 \\
275>239\end{array}$ & 28 & $\begin{array}{l}15 \\
15\end{array}$ & 0.15 \\
\hline Medroxyprogesterone acetate & MPA & ESI+ & {$[\mathrm{M}+\mathrm{H}]^{+}$} & $\begin{array}{l}387>327 \\
387>285\end{array}$ & 28 & $\begin{array}{l}16 \\
16\end{array}$ & 0.20 \\
\hline 19-Norethindrone & 19-NTD & ESI+ & {$[\mathrm{M}+\mathrm{H}]^{+}$} & $\begin{array}{l}299>231 \\
299>109\end{array}$ & 24 & $\begin{array}{l}17 \\
24\end{array}$ & 3.0 \\
\hline Melengestrol acetate & MGA & ESI+ & {$[\mathrm{M}+\mathrm{H}]^{+}$} & $\begin{array}{l}397>337 \\
397>279\end{array}$ & 26 & $\begin{array}{l}15 \\
20\end{array}$ & 0.05 \\
\hline \multicolumn{8}{|l|}{ Glucocorticoids } \\
\hline Cortisol & CRL & ESI- & {$\left[\mathrm{M}-\mathrm{CH}_{2} \mathrm{COO}\right]^{-}$} & $\begin{array}{l}421>331 \\
421>361\end{array}$ & 30 & $\begin{array}{l}16 \\
16\end{array}$ & 0.40 \\
\hline Cortisol 17 acetate & 17-CRLA & ESI- & {$\left[\mathrm{M}-\mathrm{CH}_{2} \mathrm{COO}\right]^{-}$} & $\begin{array}{l}463>403 \\
463>373\end{array}$ & 27 & $\begin{array}{l}11 \\
16\end{array}$ & 0.17 \\
\hline Cortisol 21 acetate & 21-CRLA & ESI- & {$\left[\mathrm{M}-\mathrm{CH}_{2} \mathrm{COO}\right]^{-}$} & $\begin{array}{l}463>403 \\
463>373\end{array}$ & 27 & $\begin{array}{l}11 \\
16\end{array}$ & 0.26 \\
\hline Cortisol 17 -valerate & 17-CRLV & ESI- & {$\left[\mathrm{M}-\mathrm{CH}_{2} \mathrm{COO}\right]^{-}$} & $\begin{array}{l}505>455 \\
505>331\end{array}$ & 20 & $\begin{array}{l}10 \\
16\end{array}$ & 0.12 \\
\hline Cortisol 21-valerate & 21-CRLV & ESI- & {$\left[\mathrm{M}-\mathrm{CH}_{2} \mathrm{COO}\right]^{-}$} & $\begin{array}{l}505>455 \\
505>331\end{array}$ & 20 & $\begin{array}{l}10 \\
16\end{array}$ & 0.18 \\
\hline Betamethasone & BET & ESI- & {$\left[\mathrm{M}-\mathrm{CH}_{2} \mathrm{COO}\right]^{-}$} & $\begin{array}{l}451>361 \\
451>391\end{array}$ & 27 & $\begin{array}{l}16 \\
11\end{array}$ & 0.44 \\
\hline Dexamethasone & DEX & ESI- & {$\left[\mathrm{M}-\mathrm{CH}_{2} \mathrm{COO}\right]^{-}$} & $\begin{array}{l}451>361 \\
451>391\end{array}$ & 27 & $\begin{array}{l}16 \\
11\end{array}$ & 0.85 \\
\hline Betamethasone acetate & BETA & ESI- & {$\left[\mathrm{M}-\mathrm{CH}_{2} \mathrm{COO}\right]^{-}$} & $\begin{array}{l}493>433 \\
493>353\end{array}$ & 20 & $\begin{array}{l}12 \\
18\end{array}$ & 0.33 \\
\hline Dexamethasone acetate & DEXA & ESI- & {$\left[\mathrm{M}-\mathrm{CH}_{2} \mathrm{COO}\right]^{-}$} & $\begin{array}{l}493>433 \\
493>353\end{array}$ & 20 & $\begin{array}{l}12 \\
18\end{array}$ & 0.48 \\
\hline Cortisone & COR & ESI- & {$\left[\mathrm{M}-\mathrm{CH}_{2} \mathrm{COO}\right]^{-}$} & $\begin{array}{l}419>331 \\
419>361\end{array}$ & 30 & $\begin{array}{l}16 \\
16\end{array}$ & 0.60 \\
\hline
\end{tabular}


TABle 1: Continued.

\begin{tabular}{lccccccc}
\hline Analyte & Abbreviation & Mode & Precursor ion & MRM transition & $\mathrm{CV}(\mathrm{V})$ & $\mathrm{CE}(\mathrm{eV})$ & $\mathrm{IDL}(\mu \mathrm{g} / \mathrm{L})$ \\
\hline \multirow{2}{*}{ Cortisone acetate } & \multirow{2}{*}{$\mathrm{CORA}$} & \multirow{2}{*}{ ESI- } & \multirow{2}{*}[\mathrm{M}-\mathrm{CH}_{2}\mathrm{COO}]{$^{-}$} & $461>371$ & 27 & 25 & 0.14 \\
& & & & $461>401$ & 27 & 16 & 0.14 \\
\hline
\end{tabular}

For all the compounds, ${ }^{a}$ is the first MRM transition used for quantification, and ${ }^{\mathrm{b}}$ is the second MRM transition used for verification.
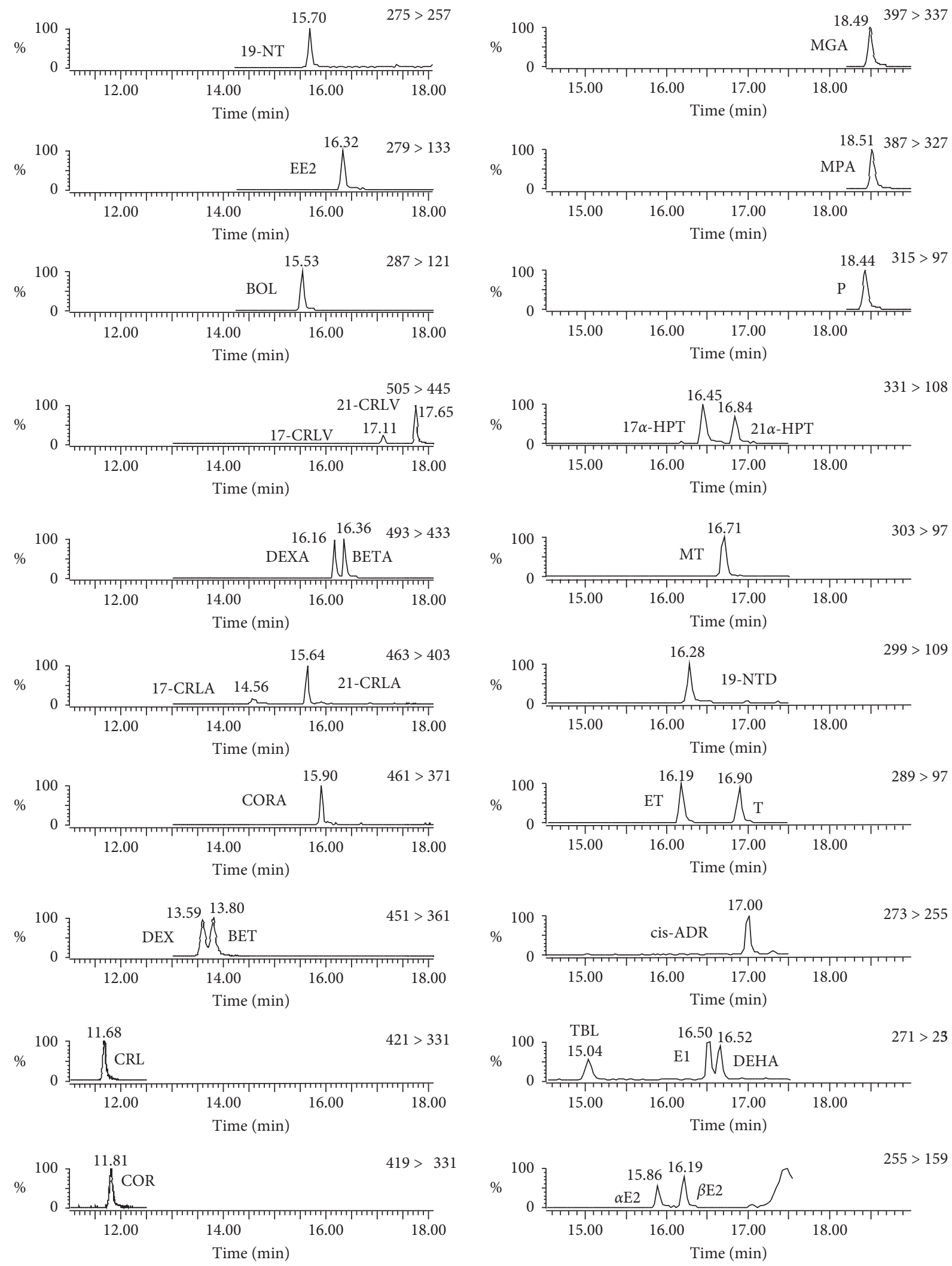

FIGURE 1: UPLC-MS/MS MRM chromatograms of target steroids. 


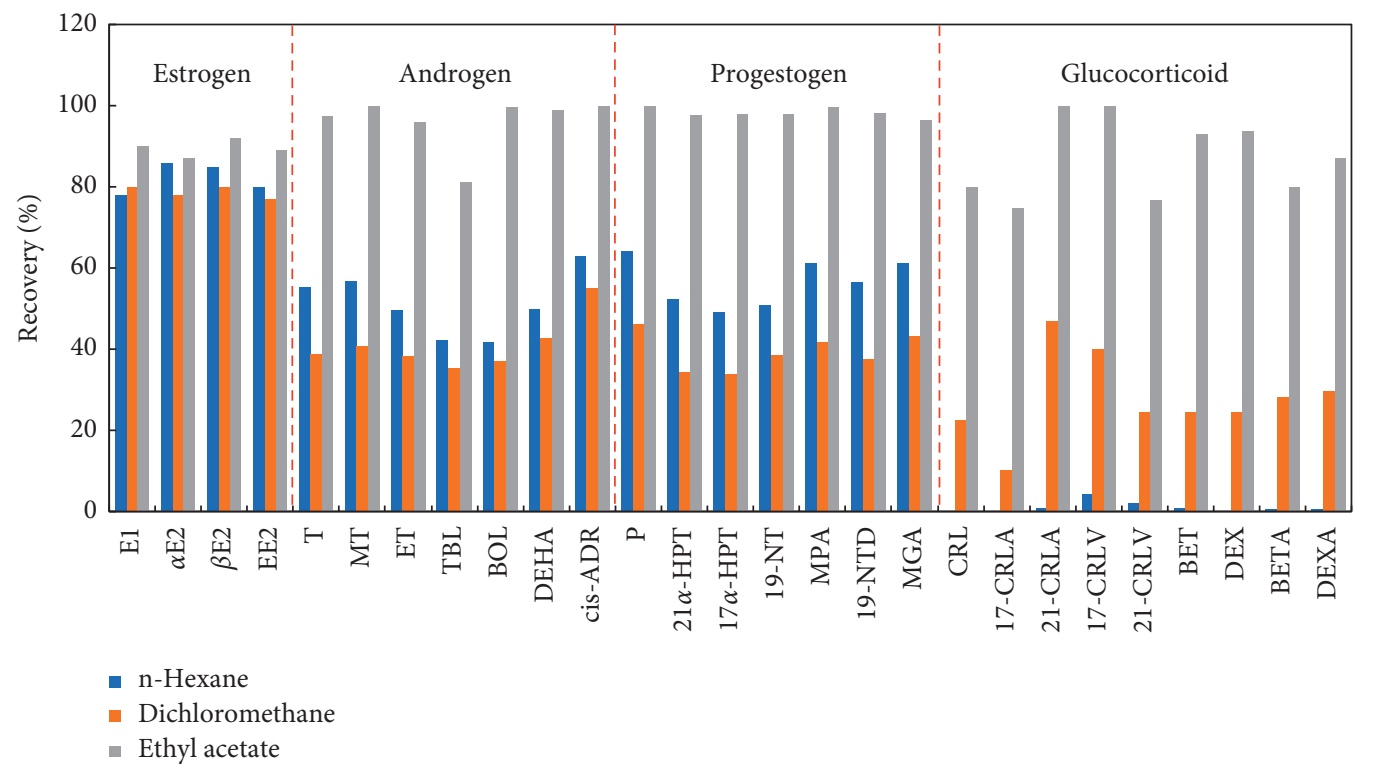

Figure 2: Recoveries (\%) of target steroids with different elution solvents.

glucocorticoids were $[\mathrm{M}-\mathrm{OH}]^{+}$and $\left[\mathrm{M}-\mathrm{CH}_{2} \mathrm{COO}\right]^{-}$, respectively, while the precursor ions for androgens and progestogens were protonated molecular ions $\left([\mathrm{M}+\mathrm{H}]^{+}\right)$.

Chromatographic separation is important for the clear identification of the 29 target steroids because some of the target compounds were isomers with identical precursor and product ions. In this study, the use of $\mathrm{C} 18$ column chemistry failed to effectively separate some isomers. Thus, we also evaluated HSS T3 columns, which afforded better separation and retention of all of the target compounds. The LODs were estimated based on the peak-to-peak noise of the baseline near the peak of the analyte. The LODs were determined as the concentration with a minimum $\mathrm{S} / \mathrm{N}$ ratio of 3 . Figure 1 shows the UPLC-MS-MS chromatogram of the 29 steroids in less than $20 \mathrm{~min}$. Very low instrumental detection limits (IDLs) were obtained for the 29 analytes $(0.15-0.85 \mu \mathrm{g} / \mathrm{L})$ (see Table 1$)$.

LLE was used to extract the target steroids in the degradation experiment. Three organic solvents were evaluated, including ethyl acetate, n-hexane, and dichloromethane. As shown in Figure 2, ethyl acetate had high recoveries of estrogens, androgens, progestogens, and glucocorticoids of $87-90 \%, 61-100 \%, 96-100 \%$, and $58-100 \%$, respectively. In contrast, the low polar solvents, n-hexane and dichloromethane, produced very low recoveries $(1-30 \%)$ for glucocorticoids, which was expected as glucocorticoids are polar compounds with $\log$ Kow of approximately 1 . For estrogens, the three solvents produced similar recoveries. For androgens and progestogens, the recoveries of $\mathrm{n}$-hexane and dichloromethane were $38-57 \%$. Thus, ethyl acetate was selected as the extraction solvent for all four classes of steroids in this study.

3.2. Kinetics of Steroid Biodegradation. We investigated the degradation of steroids in laboratory-scale experiments, and the degradation profiles of the 29 target compounds are shown in Figure 3 . The residual steroid concentrations at $0 \mathrm{~h}$ are expressed as $100 \%$. No significant losses of the target compounds were observed in the sterile control reactions. Thus, we know that the reductions of the 29 steroids in the test groups (group A) were due to biological degradation, while the contribution from abiotic degradation, such as adsorption was very small.

For the steroids studied, aerobic biodegradation followed first-order reaction kinetics. The kinetic parameters, including half-life $\left(t_{1 / 2}\right)$ and kinetic rate constant $(k)$, are summarized in Table 2 . The degradation $t_{1 / 2}$ of estrogens, androgens, progestogens, and glucocorticoids were $1.2-8.7 \mathrm{~h}, 0.3-1.3 \mathrm{~h}, 1.4-7.7 \mathrm{~h}$, and $1.4-23.1 \mathrm{~h}$, respectively, indicating that the degradation of androgens was the fastest, followed by estrogens, progestogens, and glucocorticoids under the same experimental conditions. Thus, compounds were all nearly fully degraded after $30 \mathrm{~h}$ of digestion.

The androgens were all natural hormones, which is likely why their decomposition rates were the fastest. According to the degradation curves of androgens, almost all of which were decomposed within $3 \mathrm{~h}$ of digestion. In addition, the $t_{1 / 2}$ of androgens $(0.3-1.3 \mathrm{~h})$ was consistent with that reported by Chang et al. [8]. Estrogens including E1, $\alpha \mathrm{E} 2, \beta \mathrm{E} 2$, and EE2 were almost decomposed within $24 \mathrm{~h}$ of digestion. The decomposition rate of synthetic EE2 was much slower than that of the other three natural estrogens, which is also consistent with the results of previous studies [24-27].

Compared to natural compounds, synthetic progestogens such as MPA and MGA were also not readily degraded. The decomposition rates of glucocorticoids ranged from $1.4 \mathrm{~h}$ (COR) to $23.1 \mathrm{~h}$ (BET). It is interesting to note that most of the esterified glucocorticoids such as 17-CRLA, 21CRLA, 17-CRLV, and 21-CRLV were more persistent relative to their parent compounds; however, this was not true for halogenated glucocorticoids, such as DEX and BET. The $t_{1 / 2}$ of DEX $(17.3 \mathrm{~h})$ and BET $(23.1 \mathrm{~h})$ were significantly higher than that of their esterified compounds (DEXA: $2.5 \mathrm{~h}$; BETA: $2.0 \mathrm{~h}$ ). These results may be because the decomposition of 

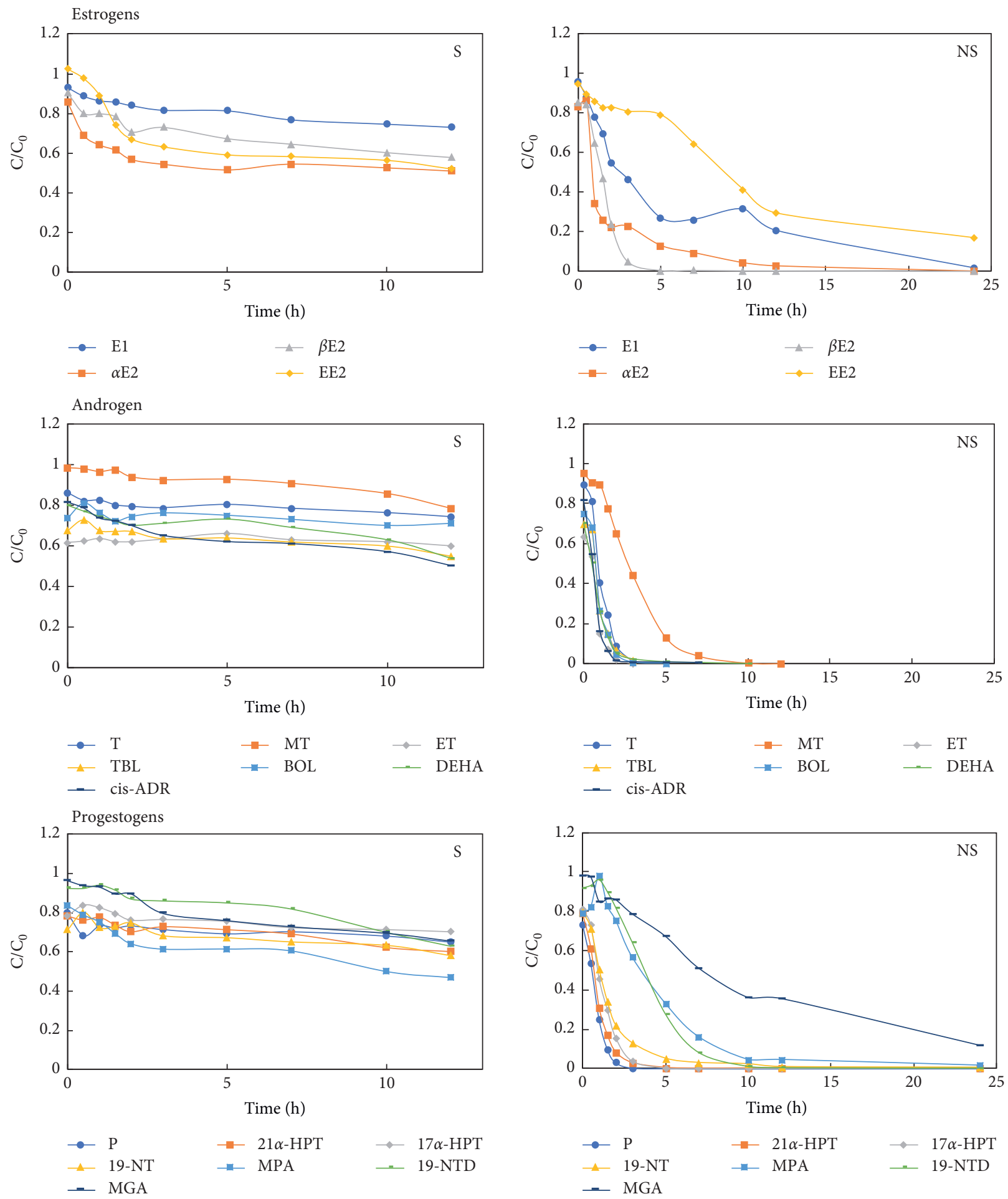

(a)

Figure 3: Continued. 

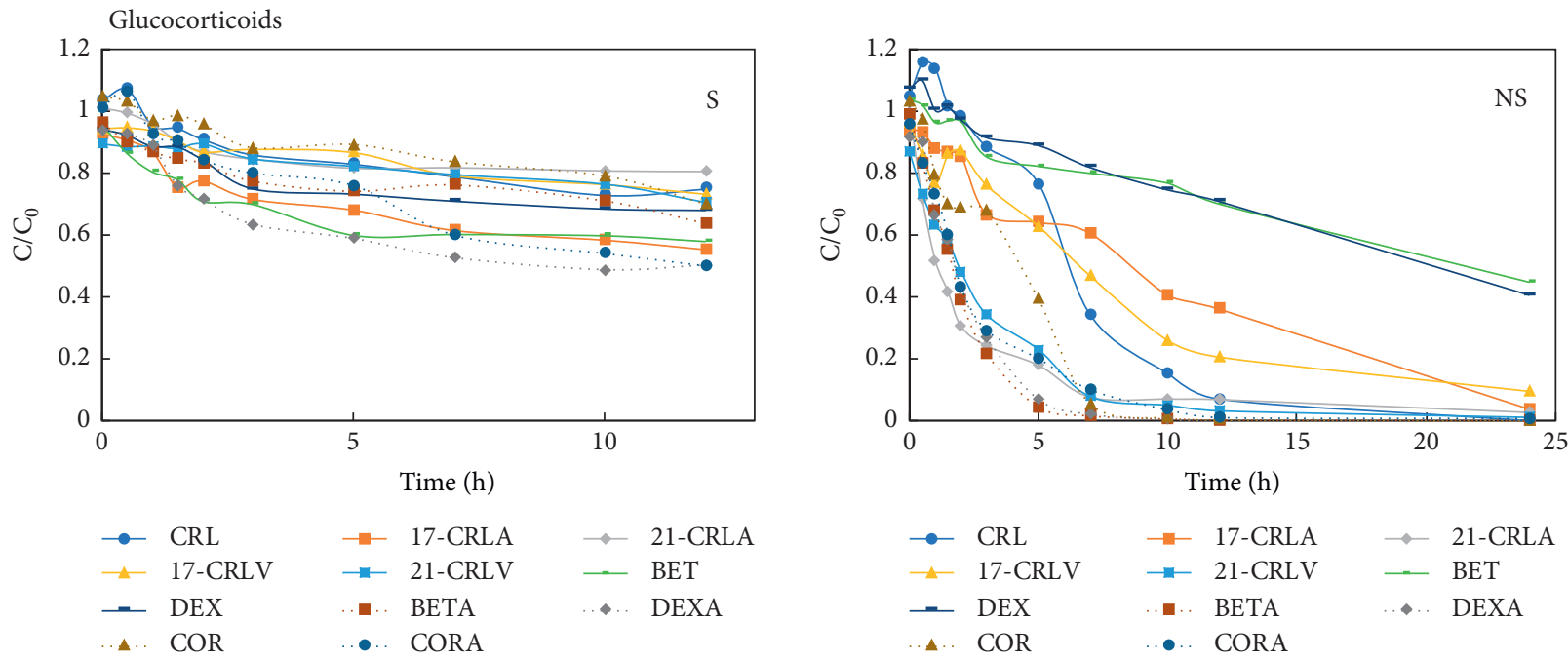

(b)

Figure 3: Degradation curves of steroids with $5 \%$ sludge concentrations. NS (nonsterile): slurry+steroids and $\mathrm{S}$ (sterile): slurry + steroids $+\mathrm{HgCl}_{2}$.

TABLE 2: Degradation parameters of the first-order kinetics model.

\begin{tabular}{lccc}
\hline Analyte & \multicolumn{3}{c}{ First-order kinetics } \\
& $k_{1}\left(\mathrm{~h}^{-1}\right)$ & $t_{1 / 2}(\mathrm{~h})$ & $r^{2}$ \\
\hline Estrogens & & & \\
E1 & 0.16 & 4.3 & 0.9407 \\
$\alpha$ E2 & 0.26 & 2.7 & 0.9268 \\
$\beta$ E2 & 0.59 & 1.2 & 0.8909 \\
EE2 & 0.08 & 8.7 & 0.9526 \\
Androgens & & & \\
T & 1.51 & 0.5 & 0.9466 \\
MT & 0.57 & 1.2 & 0.9817 \\
ET & 2.02 & 0.3 & 0.9762 \\
TBL & 1.35 & 0.5 & 0.9773 \\
BLE & 1.56 & 0.4 & 0.9801 \\
DEHA & 0.67 & 1.0 & 0.9710 \\
C-ADR & 0.75 & 0.9 & 0.8941 \\
Progestogens & & & \\
P & 0.28 & 2.5 & 0.9002 \\
21 $\alpha$-HPT & 0.26 & 2.7 & 0.8907 \\
17 $\alpha$-HPT & 0.30 & 2.3 & 0.8936 \\
19-NT & 0.49 & 1.4 & 0.9726 \\
MPA & 0.19 & 3.6 & 0.8935 \\
19-NTD & 0.28 & 2.5 & 0.9077 \\
MGA & 0.09 & 7.7 & 0.9930 \\
Glucocorticoids & & & \\
CRL & 0.28 & 2.5 & 0.9712 \\
17-CRLA & 0.12 & 5.8 & 0.9454 \\
21-CRLA & 0.15 & 4.6 & 0.9199 \\
17-CRLV & 0.10 & 6.9 & 0.9587 \\
21-CRLV & 0.20 & 3.5 & 0.9120 \\
BET & 0.03 & 23.1 & 0.9770 \\
DEX & 0.04 & 17.3 & 0.9876 \\
BETA & 0.35 & 2.0 & 0.9262 \\
DEXA & 0.28 & 2.5 & 0.8992 \\
COR & 0.48 & 1.4 & 0.9521 \\
CORA & 0.32 & 2.2 & 0.9829 \\
\hline
\end{tabular}

halogenated glucocorticoids is more difficult than the hydrolysis of their esterified compounds. In addition, it was found that C-21 esters (21-CRLA and 21-CRLV) were prone to decomposition compared to C-17 esters (17-CRLA and 21-CRLV). Those findings are different from the recovery results reported by our recent study [11]. That study found C-17 esters were prone to hydrolysis in pure water, even under neutral conditions. Thus, hydrolysis did not significantly affect the decomposition of esterified steroids in this study.

The first-order kinetics model was applied to fit the degradation results. $\mathrm{C}_{0}$ is initial concentration of steroids $(500 \mu \mathrm{g} /$ $\mathrm{L}) ; \mathrm{C}_{t}$ is the concentrations of compounds at time $t$; and $k_{1}$ is the first-order rate constant. $t_{1 / 2}$ can be calculated as $0.693 / k_{1}$.

\section{Conclusions}

The UPLC-MS/MS method with a high selectivity and sensitivity was developed for the simultaneous determination of 29 steroids in water samples, including estrogens, androgens, progestogens, and glucocorticoids. The decomposition rate of androgens was the fastest, followed by estrogens and progestogens. The degradation of glucocorticoids was the slowest of the four groups of steroids, with DEX and BET having the longest $t_{1 / 2}$ among all such steroids. Hydrolysis did not significantly affect the decomposition of esterified steroids in this study.

\section{Data Availability}

The experimental data used to support the findings of this study are included in the article. And more detailed data are available from the corresponding author upon request.

\section{Conflicts of Interest}

The authors declare that there are no conflicts of interest regarding the publication of this paper. 


\section{Acknowledgments}

This work was financially supported by the National Natural Science Foundation of China (Nos. 41573109 and 41322025), the Fundamental Research Funds for the Central Universities (Nos. 2015ZCQ-HJ-02 and JC2015-02), and a grant from the Open Foundation of State Key Laboratory of Environmental Criteria and Risk Assessment, Chinese Research Academy of Environmental Sciences (No. SKLECRA2019OFP07).

\section{References}

[1] T. H. Hutchinson, G. T. Ankley, H. Segner, and C. R. Tyler, "Screening and testing for endocrine disruption in fish-biomarkers as "signposts," not "traffic lights," in risk assessment," Environmental Health Perspectives, vol. 114, no. Suppl 1, pp. 106-114, 2006.

[2] J. P. Sumpter and A. C. Johnson, "Lessons from endocrine disruption and their application to other issues concerning trace organics in the aquatic environment," Environmental Science \& Technology, vol. 39, no. 12, pp. 4321-4332, 2005.

[3] D. G. J. Larsson, H. Hallman, and L. Forlin, "More male fish embryos near a pulp mill," Environmental Toxicology and Chemistry, vol. 19, no. 12, pp. 2911-2917, 2000.

[4] T. J. Runnalls, N. Beresford, E. Losty, A. P. Scott, and J. P. Sumpter, "Several synthetic progestins with different potencies adversely affect reproduction of fish," Environmental Science \& Technology, vol. 47, no. 4, pp. 2077-2084, 2013.

[5] Ø. Øverli, S. Kotzian, and S. Winberg, "Effects of cortisol on aggression and locomotor activity in rainbow trout," Hormones and Behavior, vol. 42, no. 1, pp. 53-61, 2002.

[6] D. W. Kolpin, E. T. Furlong, M. T. Meyer et al., "Pharmaceuticals, hormones, and other organic wastewater contaminants in U.S. streams, 1999-2000: a national reconnaissance," Environmental Science \& Technology, vol. 36, no. 6, pp. 1202-1211, 2002.

[7] P. Labadie and H. Budzinski, “"Determination of steroidal hormone profiles along the jalle d'Eysines river (near Bordeaux, France)," Environmental Science \& Technology, vol. 39, no. 14, pp. 5113-5120, 2005.

[8] H. Chang, Y. Wan, S. Wu, Z. Fan, and J. Hu, "Occurrence of androgens and progestogens in wastewater treatment plants and receiving river waters: comparison to estrogens," Water Research, vol. 45, no. 2, pp. 732-740, 2011.

[9] Z. Fan, S. Wu, H. Chang, and J. Hu, "Behaviors of glucocorticoids, androgens and progestogens in a municipal sewage treatment plant: comparison to estrogens," Environmental Science \& Technology, vol. 45, no. 7, pp. 2725-2733, 2011.

[10] X. Shen, H. Chang, D. Sun, L. Wang, and F. Wu, "Trace analysis of 61 natural and synthetic progestins in river water and sewage effluents by ultra-high performance liquid chromatography-tandem mass spectrometry," Water Research, vol. 133, pp. 142-152, 2018.

[11] X. Shen, H. Chang, Y. Sun, and Y. Wan, "Determination and occurrence of natural and synthetic glucocorticoids in surface waters," Environment International, vol. 134, p. 105278, 2020.

[12] M. Song, S. Chu, R. J. Letcher, and R. Seth, "Fate, partitioning, and mass loading of polybrominated diphenyl ethers (PBDEs) during the treatment processing of municipal sewage," Environmental Science \& Technology, vol. 40, no. 20, pp. 6241-6246, 2006.
[13] A. Muhammad, Y. Li, Y. W. Wang et al., "Occurrence, fate, and mass balance of different classes of pharmaceuticals and personal care products in an anaerobic-anoxic-oxic wastewater treatment plant in Xiamen. China," Water Research, vol. 123, pp. 655-667, 2017.

[14] W. J. Barr, T. Yi, D. Aga, O. Acevedo, and W. F. Harper, "Using electronic theory to identify metabolites present in $17 \alpha$-ethinylestradiol biotransformation pathways," Environmental Science \& Technology, vol. 46, no. 2, pp. 760-768, 2012.

[15] Z. Li, R. Nandakuma, and N. Madayiputhiya, "Proteomic analysis of $17 \beta$-estradiol degradation by Stenotrophomonas maltophilia," Environmental Science and Technology, vol. 46, no. 11, pp. 5947-5945, 2012.

[16] W. Zheng, X. Li, S. R. Yates, and S. A. Bradford, “Anaerobic transformation kinetics and mechanism of steroid estrogenic hormones in dairy lagoon water," Environmental Science \& Technology, vol. 46, no. 10, pp. 5471-5478, 2012.

[17] O. V. Egorova, V. M. Nikolayeva, G. V. Sukhodolskaya, and M. V. Donova, "Transformation of C-19-steroids and testosterone production by sterol-transforming strains of $\mathrm{My}$ cobacterium spp," Journal of Molecular Catalysis B-Enzymatic, vol. 57, no. 1-4, pp. 198-203, 2009.

[18] P. M. Bradley, L. B. Barber, F. H. Chapelle, J. L. Gray, D. W. Kolpin, and P. B. McMahon, "Biodegradation of 17 beta-estradiol, estrone and testosterone in stream sediments," Environmental Science \& Technology, vol. 43, no. 6, pp. 1902-1910, 2009.

[19] B. Khan, L. S. Lee, and S. A. Sassman, "Degradation of synthetic androgens $17 \alpha$ - and $17 \beta$-trenbolone and trendione in agricultural soils," Environmental Science \& Technology, vol. 42, no. 10, pp. 3570-3574, 2008.

[20] S. Liu, G.-G. Ying, J.-L. Zhao et al., "Occurrence and fate androgens, estrogens, glucocorticoids and progestagens in two different types of municipal wastewater treatment plants," Journal of Environmental Monitoring, vol. 14, no. 2, pp. 482-491, 2012.

[21] A. Miyamoto, Y. Kitaichi, and K. Uchikura, "Degradation of corticosteroids during activated sludge processing," Chemical and Pharmaceutical Bulletin, vol. 62, no. 1, pp. 72-76, 2014.

[22] Z. Dong, Y. Liu, L. Duan, D. Bekele, and R. Naidu, "Uncertainties in human health risk assessment of environmental contaminants: a review and perspective," Environment International, vol. 85, no. 12, pp. 120-132, 2015.

[23] G. Yuan, Z. Dong, and J. Hu, "Uncertainty analysis in 2,3,7,8tetrachlorodibenzo-p-dioxin (TCDD) cancer dose-response for three occupational cohorts," Environment International, vol. 88, no. 3, pp. 53-59, 2016.

[24] S. Liu, G. Ying, and Y. Liu, "Degradation of norgestrel by bacteria from activated sludge: comparison to progesterone," Environmental Science and Technology, vol. 47, no. 18, pp. 10266-10276, 2013.

[25] B. J. Robinson and J. Hellou, "Biodegradation of endocrine disrupting compounds in harbour seawater and sediments," Science of the Total Environment, vol. 407, no. 21, pp. 57135718, 2009.

[26] X. Zhou and J. A. Oleszkiewicz, "Biodegradation of oestrogens in nitrifying activated sludge," Environmental Technology, vol. 31, no. 11, pp. 1263-1269, 2010.

[27] G. Ying, S. Toze, and J. Hanna, "Decay of endocrine-disrupting chemicals in aerobic and anoxic groundwater," Water Research, vol. 42, no. 4-5, pp. 1133-1141, 2008. 